\title{
鋼部材腐食損傷部の炭素繊維シートによる 補修技術に関する設計・施工法の提案
}

\author{
杉浦 江 $^{1}$ ・ 小林 朗 2 ・稲葉 尚文 3 ・本間 淳史 4 ・大垣 賀津雄 5 ・長井 正嗣 6 \\ 1正会員 川崎重工業株式会社＼cjkstart技術開発本部＼cjkstart技術研究所（† 673-8666 兵庫県明石市川崎町1-1） \\ E-mail:sugiura_hiro@khi.co.jp \\ 2正会員 日鉄コンポジット株式会社 社会資本材料事業部 技術部 \\ （干103-0024 東京都中央区日本橋小舟町3-8） \\ 3正会員 中日本高速道路株式会社 横浜支社 沼津工事事務所（ \\ （元 株式会社高速道路総合技術研究所 道路研究部） \\ 4正会員 東日本高速道路株式会社 関東支社 建設事業部（广110-0014 東京都台東区北上野1-10-14） \\ (投稿時 : 株式会社高速道路総合技術研究所 道路研究部) \\ 5正会員川崎重工業株式会社 営業推進本部 事業開発部（干105-6116 東京都港区浜松町2-4-1） \\ 6正会員 長岡技術科学大学教授 工学部環境・建設系（下940-2188 長岡市上富岡町1603-1）
}

\begin{abstract}
鋼構造物はさまざまなメカニズムにより劣化し，構造物としての性能が低下寸る。この劣化の主な原因 の 1 つ鋼材の腐食である。腐食が進行しており応力的に問題となる場合の補修方法としては, 鋼板をボ ルトや溶接により添接する当て板補修が用いられる。しかしながら，これらの方法は，大がかりな足場や 重機を必要とするため，供用中の制約条件の下でより効果的な工法が求められている.

このような中，筆者らは，腐食により損傷した鋼部材を合理的に補修することを目的として，炭素繊維 シートを用いた補修工法を開発した。本稿は，炭素繊維シートによる鋼部材の補修工法の設計・施工法を 示し，既設の実橋梁を対象とした補修効果確認試験の結果について報告するものである.
\end{abstract}

Key Words : corrosion, repair, carbon fiber sheet, CFRP, steel structure

\section{1. はじめに}

近年，高度経済成長期に建設された多くの橋梁など道 路ストックの高齢化が進行して，破壊に対する安全性確 保が問題視されてきている。このため，損傷が軽微な段 階で補修を行う予防保全の重要性が高まってきている. また，一方では予算や体制の制約がある中で，効率的か つ省力的な維持管理の進め方が求められている.

鋼構造物の損傷のうち多くを占める腐食は，供用時間 の経過とともに，その発生頻度が高くなる．代表的な鋼 構造物である橋梁においては，機能向上対策以外の損傷 が原因で架け替えとなるものの約半数は，鋼材の腐食が 原因となっている ${ }^{1)}$ ，腐食により劣化した鋼部材の補修 方法としては，腐食部のケレン・再塗装が一般的である が，腐食が進行しており応力的に問題となる場合は，そ の対策では不十分となる.この場合の補修方法としては, 鋼板をボルトや溶接により添接する当て板補修や，損傷 部材の交換などにより応力的改善を図ることとなり，大
がかりな対策となってしまうのが現状である.

そのような中，鋼構造物の補修・補強材料として，炭 素繊維シートを利用することが注目を浴びている，炭素 繊維に樹脂を含浸させ硬化させた炭素繊維強化プラスチ ック（以下，CFRP と記す）は，高弾性・高強度といっ た特性を有しており，樹脂で接着するため施工が簡易で ある. CFRP による鋼構造物の補修・補強工法について は, 要求される補強量や対象部位に応じて, いくつかの 工法が提案されている. 断面補強 ${ }^{2)}$ 队疲労き裂の補修3),4 のように，必要補強量が比較的大きくなる場合には，炭 素繊維シート数層分を工場で板状に成型硬化させた炭素 繊維プレートを用いることで，現場での含浸・接着作業 を簡略化することができる，また，溶接ビード部などの 狭险部へは，柔軟性に優れるガラス䋊維シートの適用も

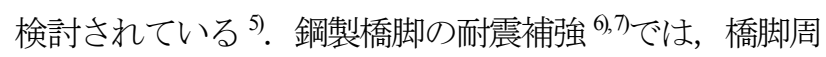
方向に䋊維シートを巻き立てて接着することで, 所定の 変形性能を確保することが一般的に行われている.

筆者らは，鋼部材の腐食損傷部を炭素繊維シートによ 
って部分的に補修する工法を開発した．本工法は，腐食 損傷した部位に対して，炭素䋊維シートに接着樹脂を含 浸させながら積層し, 現場でCFRPを形成して一体化さ せることで，設計時の初期性能を回復，もしくは現状維 持を目的とするものである. 従来の当て板補修のように， 溶接による入熱やボルト孔欠損が生じないため，母材を 傷めることもなく，供用中の制約条件の下で効率的な補 修が可能である，また，完全復旧ではなくても，当面の 延命化措置を図れる効果は実務上大きく，そのための簡 易な補修方法としての活用も期待できる.

本稿は，炭素䋊維シートを用いた鋼部材腐食損傷部の 設計・施工法を示し，既設の実橋梁に適用した事例を報 告するものである.

\section{2. 補修設計の考え方}

\section{(1) 適用の範囲}

本工法は，鋼部材の腐食損傷部の補修を対象とする. トラス橋の弦材やアーチ橋のアーチリブへの適用例を 図-1 に示す。眓に示すように，一方向炭素繊維シート を部材軸方向に，断面欠損量に応じて必要層数を貼付す る. 対象とする鋼部材とは, 鋼 I 桁橋の主桁フランジや, トラス弦材，アーチリブ等であり，適用に際しては，損 傷の種別や程度, 補修目的, 対象部材の応力状態等を十 分検討する必要がある.

表-1 には，本工法の適用対象部材を示す。一方向材 の炭素繊維シートの使用を前提とするため, 主応力方向 が一方向となる軸力部材（トラス弦材，アーチリブ）や， 曲げ部材（I 桁フランジ）が対象となる. なお，地震荷

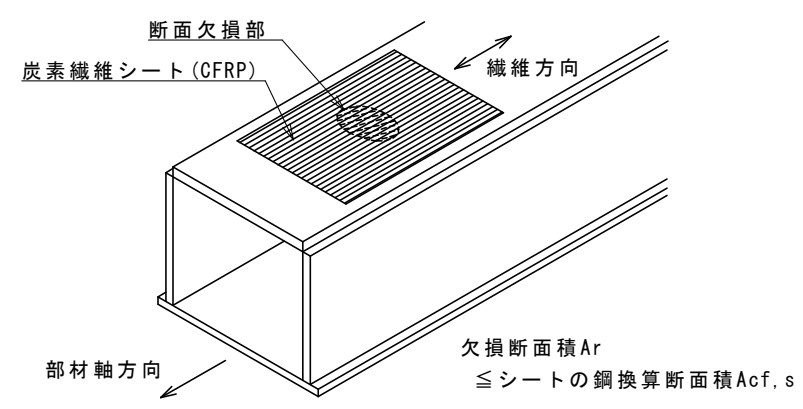

図-1 炭素繊維シートによる補修方法

表-1 炭素繊維シートによる補修の適用部位

\begin{tabular}{c|c|c}
\hline 部材 & 応力状態 & 対象部位の例 \\
\hline \multirow{2}{*}{ 軸力部材 } & 引張 & $\begin{array}{c}\text { トラス部材 } \\
\text { アーチリブ }\end{array}$ \\
\cline { 2 - 2 } & 圧縮 & 引張 \\
\hline \multirow{2}{*}{ 曲げ部材 } & I行フランジ \\
\cline { 2 - 2 } & 圧縮 & \multirow{2}{*}{} \\
\hline
\end{tabular}

注）常時荷重作用下における弾性挙動域での適用を前提
重作用下で降伏点付近の応力が作用するようなケースで は，炭素繊維シートの剥離によって，その補修効果が失 われるため, 終局耐力の向上には寄与しない. したがっ て，本工法は，常時荷重作用下で母材が弾性挙動する範 囲，すなわち炭素繊維シートの剥離が生じない範囲での 適用が前提となる。

図-2 には，塗膜劣化損傷リスクおよび断面性能と供 用期間の関係を示す. 図に示すように，上塗り・中塗り 塗装の劣化のみ（損傷レベル I）では，鋼材の腐食は発 生せず，部材の断面性能の低下はないため，ケレン・再 塗装による補修方法が一般的に採用されている.さらに， 下塗り塗装の塗膜厚の減少が進むと（損傷レベル II）， 腐食が進行し，断面欠損により断面性能が低下寸る.こ の場合，鋼板当て板や，部材取替えにより断面欠損部の 応力改善を図る必要が生じる. 本工法は, 塗膜損傷によ る腐食初期段階や断面欠損が生じた部材に適用すること で，腐食の進行を食い止め，断面欠損部の応力改善を図 るものである.

表-2 に，腐食損傷部の各種補修方法との比較を示す. 本工法は，従来の当て板補修に比べて施工性に優れ，母 材を傷めないため，施工スペースの制約がある供用中の 補修や，塗装塗替え工事に併せた補修工事に適する。ま た，CFRP が鋼部材腐食部の外的劣化要因を遮断し，而 久性と耐食性に高い効果が得られることから，初期の腐 食発生部に適用することで, 効果的な予防保全を行うこ とができる。

\section{(2) 使用材料}

\section{a) 炭素繊維シート}

炭素繊維は軽量, 高強度, 高弾性, 高耐食性などの優 れた特性を持つ高性能無機材料である. 䋊維の直径は 7 〜 $10 \mu \mathrm{m}$ で，これを 3,000〜24,000 本程度収束させたスト ランドとして工業用に使用されている. このストランド を $50 \mathrm{~cm}$ など単位幅に数百本並べた炭素繊維シート（図-

3）は，表-3 に示すように材料特性や䋊維目付け量の違

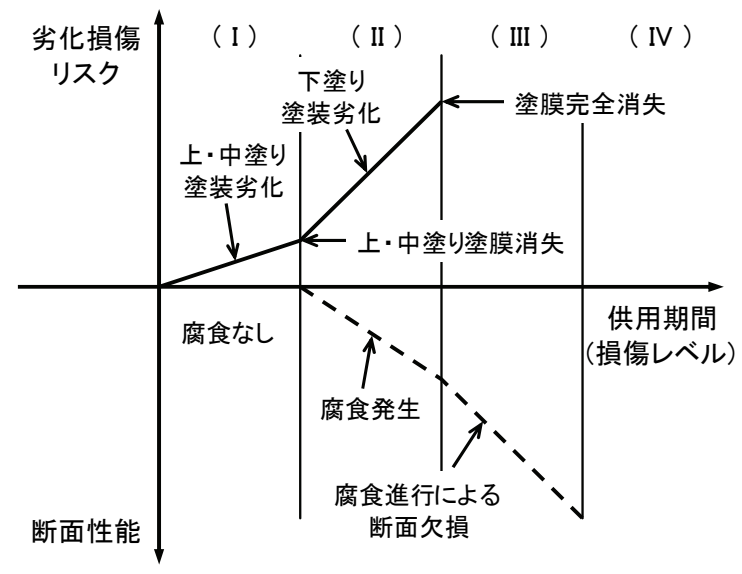

図-2 劣化損傷リスクおよび耐荷性能と供用期間8) 
表-2 腐食損傷部の補修方法

\begin{tabular}{|c|c|c|c|}
\hline 補修工法 & 適用レベル & 補修効果・母材への影響 & 施工性 \\
\hline 再塗装 & $\mathrm{I} \sim \mathrm{II}$ & $\begin{array}{l}\text { ・断面欠損部の応力改善効果はない } \\
\text { ・ケレンが十分でないと再腐食の恐れあり }\end{array}$ & $\begin{array}{l}\text { ・供用下で施工可能 } \\
\text { ・簡易的な足場で施工可能 }\end{array}$ \\
\hline $\begin{array}{l}\text { 鋼板当て板 } \\
\text { (ボルト添接) }\end{array}$ & $\mathrm{III} \sim \mathrm{IV}$ & $\begin{array}{l}\text { ・断面欠損部の応力を改善 } \\
\text { ・ボルト孔欠損, 死荷重増加が生じる } \\
\text { ・鋼板角部, 肌隙, ボルト頭が防食上の欠点 } \\
\text { となりや寸い } \\
\end{array}$ & $\begin{array}{l}\text { ・供用下で施工可能 } \\
\text { ・足場, 重機が必要 } \\
\text { ・摩擦面確保の処理が必要 } \\
\text { ・閉断面部材にはワンサイドボルトを適用 }\end{array}$ \\
\hline $\begin{array}{l}\text { 鋼板当て板 } \\
\text { (溶接) }\end{array}$ & $\mathrm{III} \sim \mathrm{IV}$ & $\begin{array}{l}\text { ・断面欠損部の応力を改善 } \\
\text { ・溶接による入熱, 死荷重増加が生じる } \\
\text { ・鋼板角部が防食上の欠点となりやすい }\end{array}$ & $\begin{array}{l}\text { ・供用下の施工に難あり } \\
\text { ・足場, 重機が必要 } \\
\text { ・母材の溶接性に要注意 }\end{array}$ \\
\hline 部材取替え & IV & ・確実な補修効果が得られる & $\begin{array}{l}\cdot \text { 交通規制が必要 } \\
\text { ・大規模な足場，重機が必要 }\end{array}$ \\
\hline CFRP 貼付 & II $\sim$ III & $\begin{array}{l}\text { • 断面欠損部の応力を改善 } \\
\text { ・ 母材と密着するため対象部位の防食性向上 } \\
\text { • 母材への加工，死荷重増加は生じない }\end{array}$ & $\begin{array}{l}\text { ・供用下で施工可能 } \\
\text { ・簡易的な足場で施工可能 } \\
\text { ・接着性を確保寸るためのケレンが必要 } \\
\text { (多少の凸凹は許容) }\end{array}$ \\
\hline
\end{tabular}

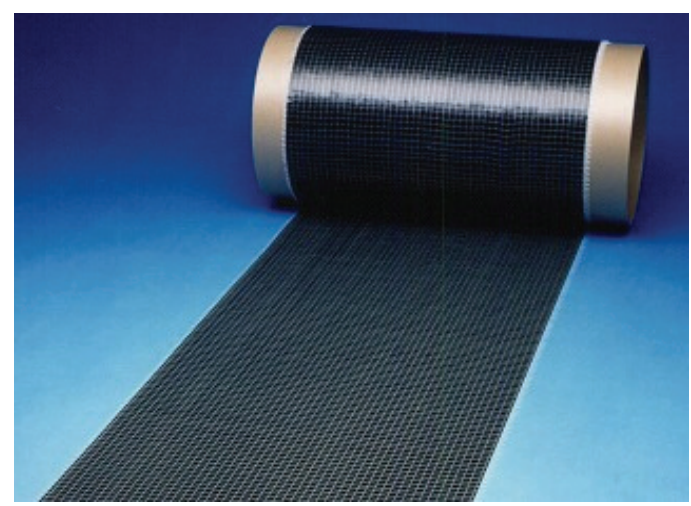

図-3 炭素繊維シート

表-3 炭素䋊維シートの材料特性

\begin{tabular}{c|c|c|c}
\hline 種類 & $\begin{array}{c}\text { 引張強度 } \\
\left(\mathrm{N} / \mathrm{mm}^{2}\right)\end{array}$ & $\begin{array}{c}\text { ヤング係数 } \\
\left(\mathrm{kN} / \mathrm{mm}^{2}\right)\end{array}$ & $\begin{array}{c}\text { 繊維目付 } \\
\left(\mathrm{g} / \mathrm{m}^{2}\right)\end{array}$ \\
\hline 高強度 & 3400 & 230 & $200 \sim 600$ \\
\hline 中弾性 & $2900 \sim 2400$ & $390 \sim 440$ & 300 \\
\hline 高弾性 & 1900 & $540 \sim 640$ & - \\
\hline 鋼 & $400 \sim 570$ & 200 & - \\
\hline
\end{tabular}

いにより数種類が製品化されている，一般には， $\mathrm{RC}$ 橋 脚の而震補強など高い引張耐力が要求される場合には, 高強度型の炭素繊維シートが広く用いられ，常時荷重に 対する既設鉄筋の応力度低減や，たわみの低減が要求さ れる場合には，ヤング係数が高い高弾性型の炭素繊維シ 一トを用いた方が積層数を少なく抑えることができる. 本工法の目的は，常時荷重作用下における断面欠損部の 応力改善であり，鋼材の弾性挙動範囲内での使用を前提 としている．また，工期や剥離強度の面から，積層数を 少なく抑えることが有利となる，そのため，本工法では 高弾性型の炭素繊維シートを使用寸ることを標準とした。
なお，近年，工事費および工期の短縮を図ることを目的 として, 繊維目付け量 $600 \mathrm{~g} / \mathrm{m}^{2}$ の高目付け炭素繊維シー トも開発されている。ただし, 䋊維目付け量が多くなる と，接着樹脂の含浸が困難になり，接着樹脂の選定も含 めて, 事前の十分な検証が必要となるため, 現状は，コ ンクリート構造物の補強で使用実績がある繊維目付け量 $300 \mathrm{~g} / \mathrm{m}^{2}$ の製品を使用する.

また，炭素繊維にあらかじめ樹脂を含浸させ工場で板 状に成型硬化させた炭素繊維プレートも製品化されてい る. 1 枚のプレートで炭素繊維シート数層分の耐力, 剛 性を有するため, 必要補強量が大きい場合には, 現場で の積層作業を低減することができる，しかしながら，炭 素繊維シートを現場で含浸する方法と比べて，貼付対象 に不陸がある場合の接着性は劣る，例えば，突合わせ溶 接継手部のような鋼材表面に段差がある場合でも，柔軟 性を有する炭素繊維シートであれば，貼付対象の形状に 馴染ませて，母材に密着させることが可能である.さら に，腐食減肉が問題となる場合は，構造的もしくは環境 的な要因によって，極限られた範囲で集中的に腐食が進 行し，損傷部位は一箇所に集中せずに，細かな損傷が広 範囲に渡って点在しているケースも見られる。そのよう な場合, 現場でのハンドリングに優れ, 任意の形状にカ ットすることが容易な炭素䋊維シートを使用する方が, 部分的な補修への対応が容易になると考えた。

図-4 には，繊維強化プラスチック材に一般的に使用さ れる各種繊維の比弾性率 (弾性率/質量) と比強度（強 度/質量）の関係を示す 9,10). このように，高弾性型の炭 素繊維は，単位重量あたりの剛性が高い. よって，同じ 鋼換算断面積を確保する場合，他の繊維に比べて軽量， すなわちシート枚数を少なくできるため, 本工法にもつ とも適した強化繊維であるといえる。 


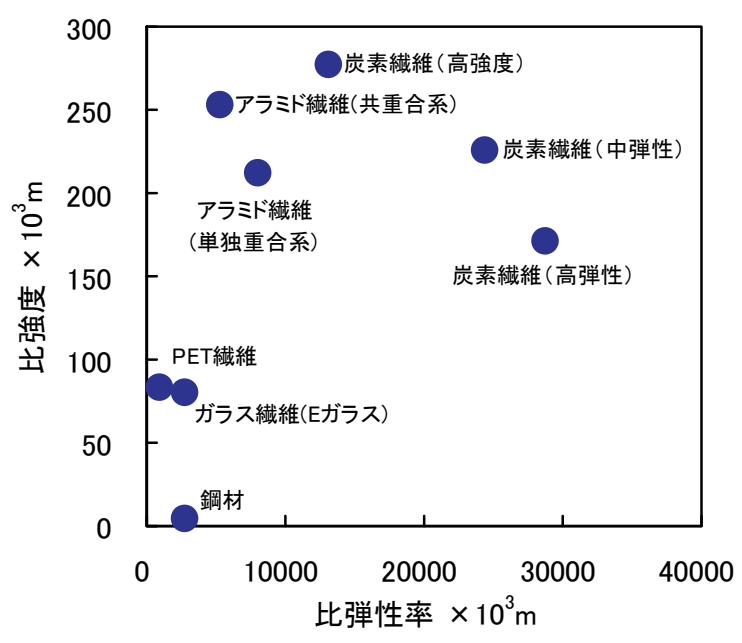

図-4 各種強化繊維の比強度と比弾性率の関係

\section{b) 樹脂材料}

エポキシ樹脂は，FRPの結合材として，あるいはコン クリートや金属材料の接着剂として最も広く利用されて いるもので，一般に主剤と硬化剤からなる 2 液型のもの が用いられている. エポキシ樹脂の特徵としては, 連続 繊維や金属, コンクリートとの接着性が高い, 耐アルカ リ性や耐衝撃性が良好である，硬化時の収縮が小さく寸 法安定性に優れていることなどがある. 2 液硬化型エポ キシ樹脂は，主剤と硬化剤を混合するまで硬化反応が進 行せず，常温で保存可能で保存安定性に優れている. エ ポキシ樹脂には，加熱硬化型と常温硬化型があるが，現 場施工する連続繊維シート接着工法の場合には，施工現 場での加熱処理が不要な常温硬化型エポキシ樹脂が用い られている.

本工法で用いる樹脂材料は，プライマー，不陸修正 材および含浸接着樹脂の 3 つである.いずれもエポキシ 樹脂を主成分としているが，用途に合わせて粘度などの 特性を調整している.

プライマーは，比較的低粘度で鋼材との濡れ性が良 くまた凹部にも浸透して薄い塗膜が形成できる. そのた め, 次工程で塗布する不陸修正材や含浸接着剤と鋼材と の接着性を確保するとともに，下地処理後の鋼材の腐食 防止，鋼材と炭素繊維との絶縁層として機能する.

不陸修正材は，孔食部など鋼材表面の凹部に充てん して平坦にするのに適した粘性の高いペースト状の樹脂 であり，含浸接着剤と同等の接着強度を有する.

含浸接着剤は，炭素繊維シートと鋼材表面との接着 剤として機能すると同時に炭素繊維の素線の間に浸透し て FRP の結合材となる.このため, シートの貼り付け 時にシートを補強材表面に保持すると同時に炭素繊維の 素線の間に容易に浸透できるように粘度やチクソ性を調 整したものである. CFRP の引張強度などの材料特性は, 炭素䋊維のみでなく結合材である含浸接着剤の影響も強

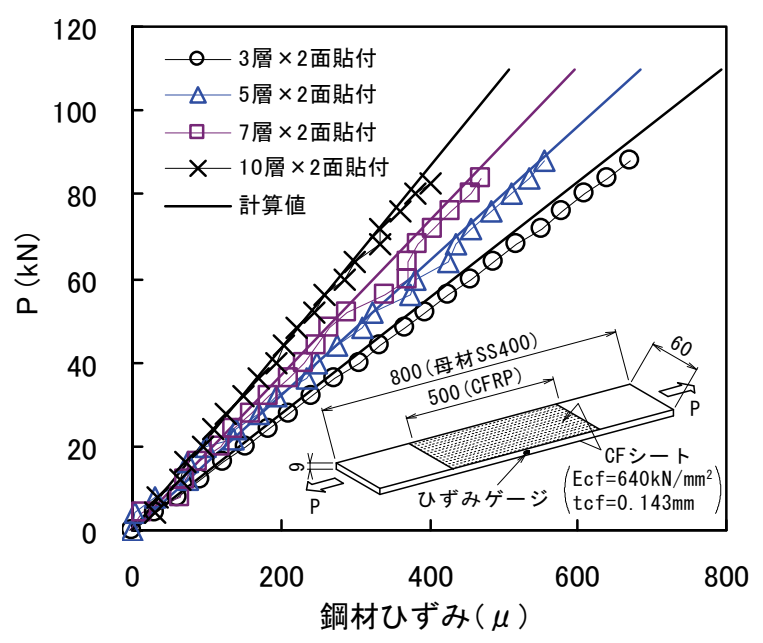

図-5 炭素繊維シート積層数の影響（荷重一ひずみ関係）

く受けるので，炭素纎維との組み合わせで CFRP の材料 特性が確認されたものが使用されている.

\section{（3）補修量（炭素繊維シート積層数）の決定}

炭素䋊維シートを鋼材に貼付し引張試験を実施した結 果を図-5 に示す ${ }^{11)}$. 図中の計算值は, 式(1), 式(2)によ り計算した。

$$
\begin{aligned}
\varepsilon_{s} & =\frac{P}{E_{s} \cdot\left(A_{s}+A_{c f, s}\right)} \\
A_{c f, s} & =\frac{E_{c f}}{E_{s}} \times B_{c f} \times t_{c f} \times n
\end{aligned}
$$

ここで， $\varepsilon_{s}$ : 鋼材の発生ひずみ

$E_{s}$ : 鋼材のヤング係数 $\left(\mathrm{kN} / \mathrm{mm}^{2}\right)$

$E_{c f} \quad$ : 炭素繊維シートのヤング係数 $\left(\mathrm{kN} / \mathrm{mm}^{2}\right)$

$A_{s}$ : 鋼材の断面積 $\left(\mathrm{mm}^{2}\right)$

$A_{c f, s}$ : 炭素䋊維シートの鋼換算断面積 $\left(\mathrm{mm}^{2}\right)$

$B_{c f} \quad$ : 炭素繊維シートの幅(mm)

$t_{c f}$ : 炭素繊維シート1枚あたりの厚さ $(\mathrm{mm})$

$n$ : 炭素繊維シートの積層数

$P \quad$ : 引張荷重 $(\mathrm{kN})$

この結果より，炭素繊維シートを鋼材に貼付すること で，積層数に応じた応力改善効果が得られる.よって, 設計時の初期性能への回復を目的とした場合，炭素繊維 シートの鋼換算断面積 $A_{c f, s}$ が，断面欠損量 $A_{s l}$ と同等 以上になるように, 式(3)により, 炭素繊維シートの積 層数を決定する.

$$
\frac{E_{c f}}{E_{s}} \times t_{c f} \times B_{c f} \times n=A_{c f, s} \geqq A_{s l}
$$


筆者らは，断面欠損した鋼部材の補修効果確認実験を 行っており ${ }^{12)}$, 図-6に示寸試験体の引張側フランジまた は圧縮側フランジを炭素繊維シートで補修し，断面欠損 部の応力が改善されることを示した．図-7 には引張側 フランジの補修効果の例を示寸。このことから，本工法 に関する設計方法の妥当性を検証している.

なお，樹脂のヤング係数は，炭素繊維のヤング係数の 1/100 以下程度であり, 樹脂の体積比が 70〜80\%である ことから，CFRP 全体の引張岡性に及ぼす樹脂の影響は $5 \%$ 程度である 》。．そのため，CFRP の計算には炭素纎維 シートのみの断面積を用いており，樹脂は見込んでいな い. 現場で樹脂を含浸させて CFRP を形成する場合, CFRP の厚さを管理することは困難であり，設計上は炭 素繊維のみの断面積を用いることが実用的といえる.

また, 本工法は, 部材としての平均応力を改善するこ とが目的であるため，損傷箇所を含む断面全体で，必要 補修量を満足すれば良いものとした。これにより，図-8 に示すように，炭素繊維シートの貼付範囲や，貼付箇所

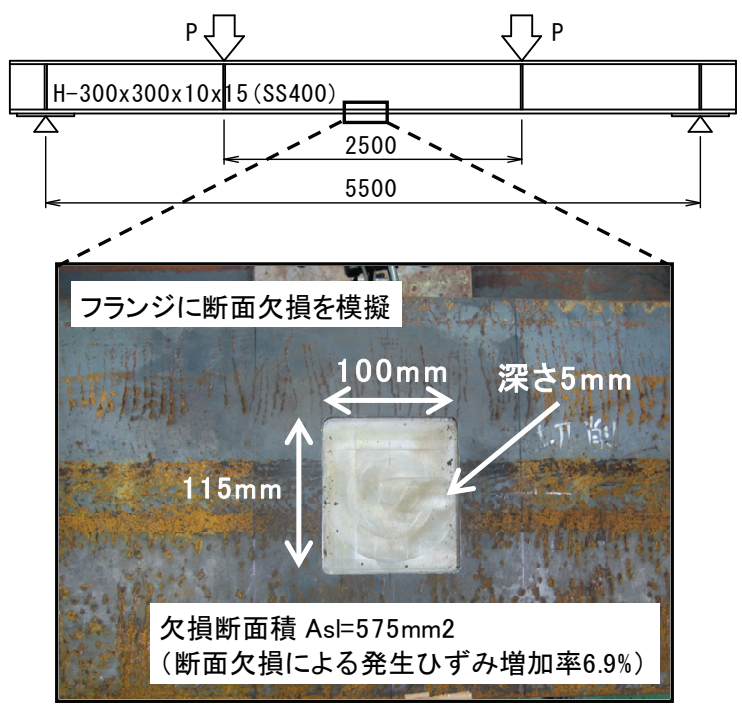

図-6 補修効果確認実験の概要

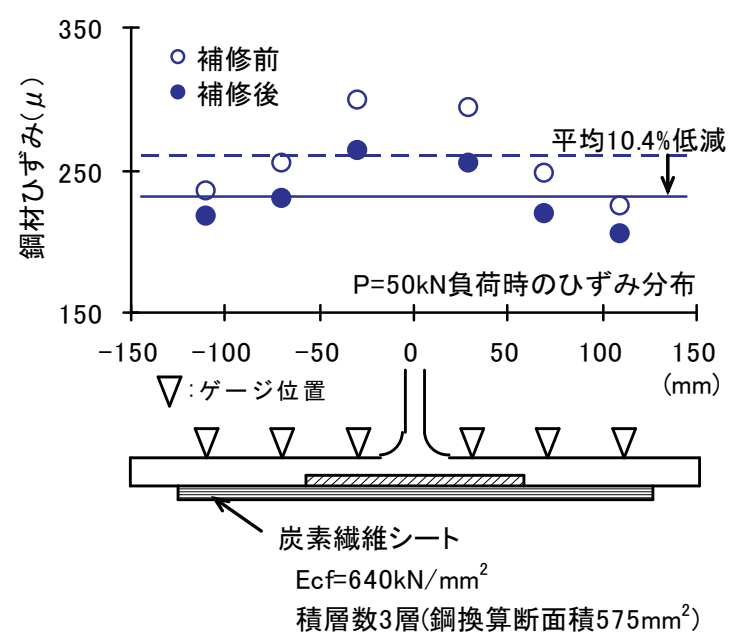

図-7 炭素繊維シートによる補修効果
を最適化することで, 炭素繊維シートの積層数を極力抑 えることができ，現場での施工性の向上を図ることがで きる.

\section{（4）許容荷重}

\section{a) 考慮すべき荷重}

炭素繊維シートの引張強度は, 鋼材に比べて十分大き $<$, 炭素繊維シート自体の許容応力度が問題となること はほとんどない，しかしながら，実験の結果では，鋼材 降伏点の 50\%程度で CFRP が剥離するケースもある ${ }^{11}$.

図-9 には，引張荷重を鋼材のみの断面積で除した公称 応力と, 鋼材および CFRP に発生する試験片中央部のひ ずみの関係を示す。試験片は, 図-5 に示した試験片と 同形状で，炭素繊維シート 5 層を貼付した場合の例であ る.このように，CFRP の剥離が生じると，CFRP のひ ずみは急減し, 応力改善効果は消失するため, 供用下で の作用荷重に対して，CFRP の剥離が生じないことを確 認する必要がある。

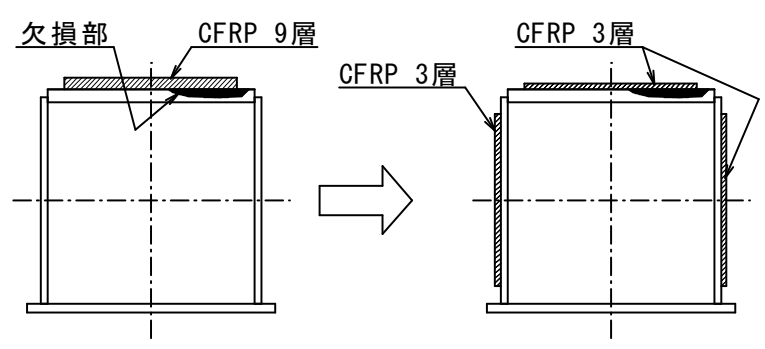

a)トラス部材の例

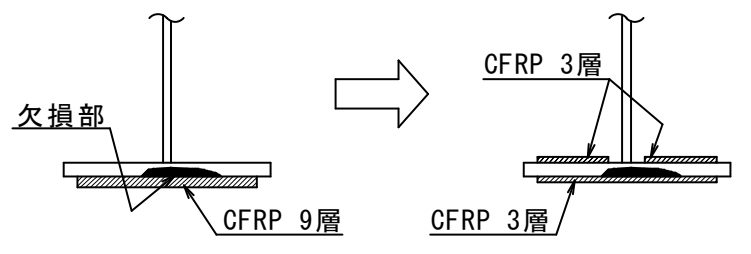

b）鈑桁フランジ部材の例

図-8＼cjkstart炭素䋊維シート積層数を低減した例

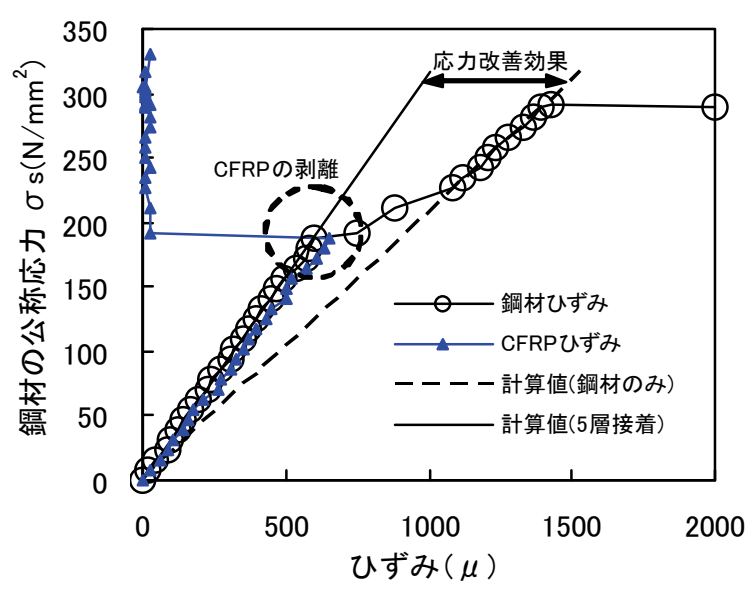

図-9 炭素繊維シート接着鋼板の荷重一ひずみ関係 
本工法は，既設構造物への補修を対象としており，死 荷重が既に作用している状態で炭素䋊維シートを接着す るため, CFRP はこれを負担しない. よって, 補修設計 荷重としては，死荷重以外の活荷重や温度荷重を考慮す ればよい. ただし，CFRP の剥離によって，終局耐力の 向上には寄与しないため, 而震補強のように降伏点付近 の応力が作用する場合は, 留意する必要がある.

\section{b) CFRPの剥離荷重}

CFRP の剥離は，接着端部の応力集中により生じるた め，積層毎にずらして接着して応力集中を緩和すること が望ましい，図-10 は，接着界面での水平せん断応力の 分布を調べた解析結果である ${ }^{13)}$. 接着端をずらした場合， 2３ 層目の接着端（ $\delta=10 \mathrm{~mm}$ で $\mathrm{x}=10 \sim 20 \mathrm{~mm}, \quad \delta=25 \mathrm{~mm}$ で $\mathrm{x}=25 \sim 50 \mathrm{~mm}$ ) では水平せん断応力に乱れが生じるも のの, 剥離起点となる 1 層目の接着端（x=0mm）では, 端部のずらし量を増すことで, 水平せん断応力を緩和で きることがわかる。

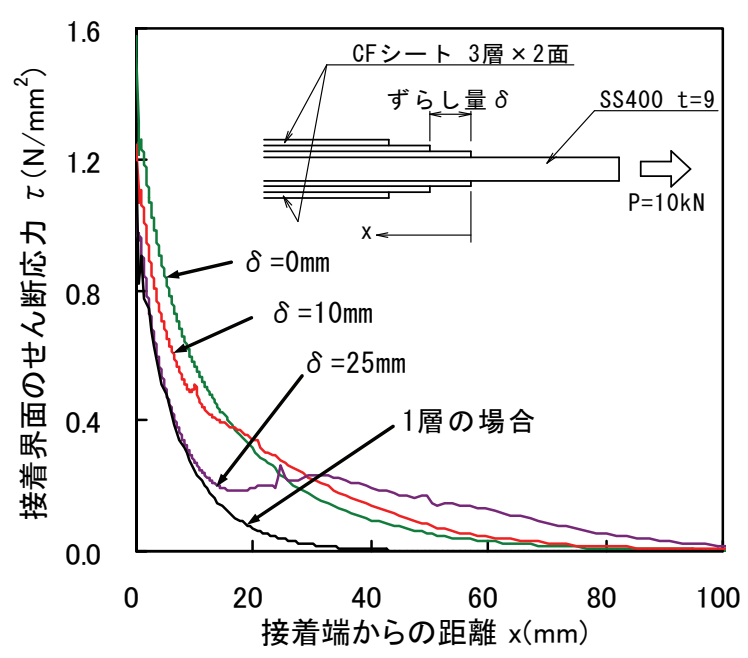

図-10 接着界面の水平せん断応力

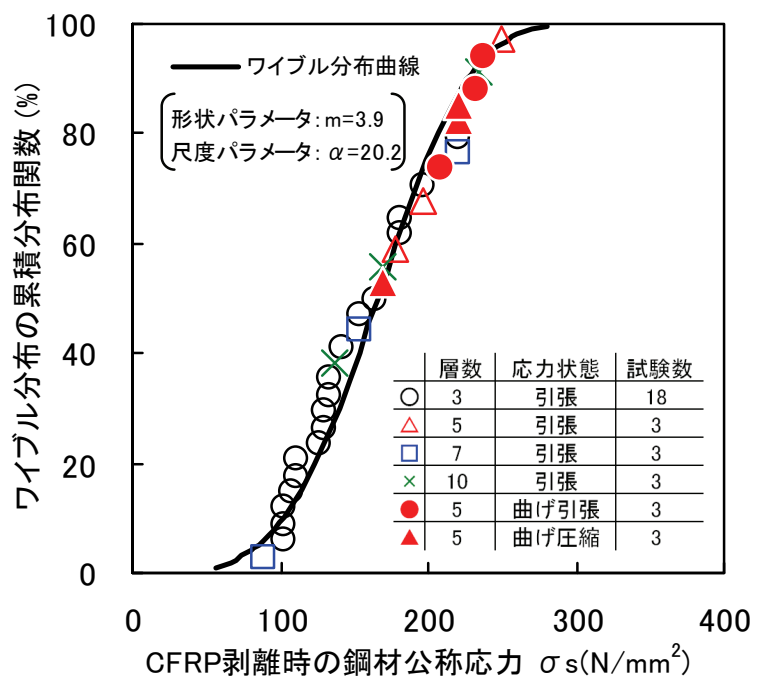

図-11 CFRP の剥離荷重
また，炭素繊維シートの貼付は手作業による樹脂塗布 によって行うため, 仕上がり厚さ等は均一とならず, CFRP の剥離強度はある值を中心にバラツキを示す。よ って, 確率統計手法による剥離強度の評価を行った結果 を図-11 に示す. 図は，炭素繊維シートを貼付した鋼材 を引張または曲げ試験し，CFRP の剥離が生じた際の公 称応力にワイブル分布を適用した結果である。試験体は, 図-5, 図-6 に示した引張試験片, 曲げ試験体と同形状で ある. CFRP の剥離は, 引張応力下では全ての試験体で 接着端より，鋼材と CFRP の界面で生じた。また，圧縮 応力下では, 明確な剥離は観察されなかったが, CFRP ひずみが急減した時点を剥離荷重とした ${ }^{12}$. この結果に よれば，母材の発生応力が $100 \mathrm{~N} / \mathrm{mm}^{2}$ 程度の場合, 剥離 発生確率は $10 \%$ 以下である.

\section{(5) CFRPの耐久性について}

\section{a) CFRP の温度変化に対する耐久性}

炭素䋊維シートは，樹脂との複合材である CFRP の状 態で線膨張係数が $0 \sim 1 \times 10^{-6} \% \mathrm{C}$ 程度であり，鋼材の線膨 張係数に比べてほぼ 1 桁小さい. 鋼材に炭素䋊維シート を接着した後, 温度サイクル $\left(20^{\circ} \mathrm{C} \sim 60^{\circ} \mathrm{C}\right)$ を 100 回負荷 した確認試験 ${ }^{14), 15)}$ によると, 温度サイクル終了時点まで 炭素繊維シートの剥離や破断は発生せず，温度サイクル 負荷後の引張試験結果は温度サイクル負荷前の結果と変 わりないことが確認されている.

\section{b) 紫外線による CFRP の劣化度}

炭素繊維自身は紫外線劣化することなく，また，紫外 線の遮蔽効果が高いので紫外線による劣化が CFRP のご く表層の樹脂層のみで生じる. 図-12 には, サンシャイ ンカーボンアーク灯式（JIS A1415）により促進暴露した CFRP シートの引張試験結果を示す ${ }^{16}$. CFRP シートは, 高強度型炭素繊維シートにエポキシ樹脂を含浸硬化させ

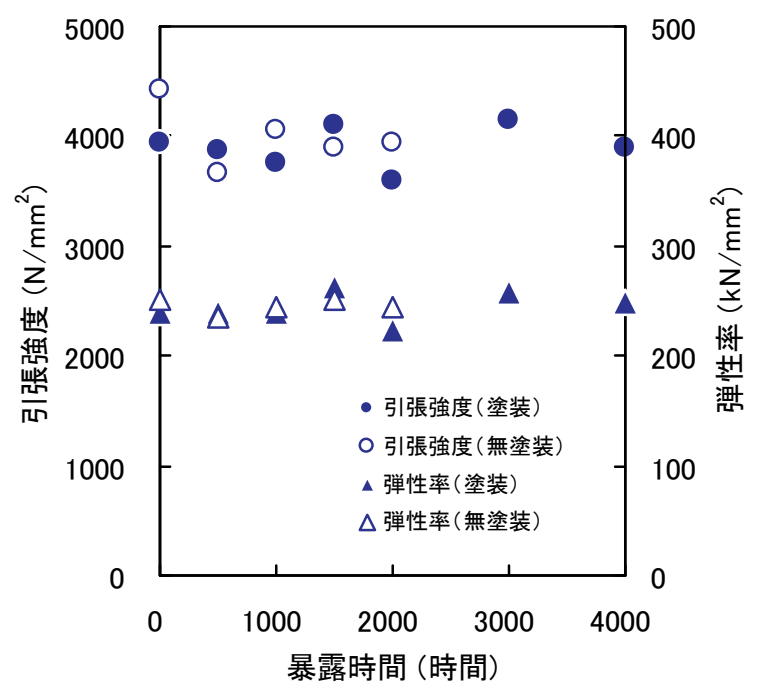

図-12 促進暴露後の引張試験結果 
たもので無塗装のものと表面にウレタン塗装を施したも のの 2 種類を準備した． 無塗装のものは 2,000 時間まで, 塗装を施したものは 4,000 時間まで暴露し, 暴露後 JS K7073 に準じて引張試験を行った，無塗装供試体，塗装 供試体いずれも引張強度, ヤング係数ともに低下しなか った.

\section{3. 施工方法}

\section{(1) 施工手順}

施工は以下に示す手順で実施する.

\section{a) 下地処理}

炭素繊維の有する弾性率を発揮して補修効果を得るた めには，母材との接着性が十分に確保されている必要が ある. 接着面に塗膜が残置している場合, 塗膜のせん断 変形によって CFRP に荷重が十分に伝達されず, 所要の 補修効果が得られないといった実験結果もある ${ }^{15}$. 所要 の補修効果を得るためには，鋼材素地に直接接着寸る必 要があるため, 表面の塗料や錆をディスクサンダーなど により除去する．また，鋼材表面に油分などの污れがあ ると，炭素繊維シートと鋼材の接着性に悪影響を及ぼす ので，有機溶剤などを用いて鋼材表面を清掃する必要が ある.

\section{b) プライマーの塗布}

下地処理を施した鋼材表面は, 錆が発生しや寸いため, 下地処理後, 速やかにプライマーを塗布する. 炭素繊維 の素線が鋼材表面に直接接触し，水がこの部分に浸入す ると電食を起こすことがある ${ }^{14,17)}$. 電食を防止する目的 で，プライマーをむらなく塗布して鋼材表面に電気的絶 縁層を形成し，炭素繊維の素線が直接，鋼材表面に接触 しないようにしなければならない。

\section{c) 不陸調整}

損傷による減肉が大きい箇所や孔食部などの不陸は, 炭素繊維シートの浮き，膨れ，たるみ，しわなどの施工 不良の原因となる，そのため，貼付け箇所を樹脂系パテ （不陸修正材）により, 平坦に処理するものとする.

\section{d) 炭素䋊維シート貼付け}

施工面積に合わせて所定の寸法に切断した炭素繊維シ ートを含浸樹脂により積層する. プライマーが乾燥した 後, 含浸樹脂を下塗りし, 炭素繊維シートの繊維方向を 部材軸方向に合わせて貼り付ける．この際，脱泡ローラ 一やゴムへラを使用し，炭素繊維方向に気泡を除去しな がら貼り付ける. その後, さらに含浸樹脂を上塗りし， 炭素䋊維シート内に十分エポキシ樹脂を含浸させる。こ れを繰り返して, 必要層数の炭素䋊維シートを貼り付け る.

\section{e) 養生}

含浸樹脂が初期硬化するまでは，雨水や砂，ホコリな どの付着を防止すると共に, 気象の急変などによる悪影 響を受けないように，必要に応じてビニルシートなどで 養生を行う. 含浸樹脂の指触乾燥状態が初期硬化の目安 となる.

\section{f) 仕上げ · 保護}

炭素繊維シートは, 屋外暴露試験や促進暴露試験によ り耐久性に優れていることが確認されている。しかしな がら, 含浸接着樹脂や不陸修正材は紫外線やオゾンの作 用により劣化し, 白化や黄変など変色し美観を損なうこ とがあるため, 塗装を行うことが望ましい，表面保護の 塗装系は, 既設の塗装系および含浸接着樹脂とのマッチ ングを考慮する必要がある，中塗りにエポキシ樹脂系塗 料を用いれば，含浸樹脂（エポキシ）と仕上げ塗膜との 接着性を確保できるため, エポキシ樹脂系中塗塗料との 相性を確認すれば，種々の上塗剤が使用できる.

\section{(2) 施工上の留意点 \\ a) 樹脂の塗布量}

樹脂の塗布は，ローラー刷毛を用いて手作業で実施す るため, 現場で樹脂の塗布厚さを管理することは困難で あり，樹脂の使用量で施工管理を行う。標準使用量は, 使用寸る繊維と樹脂の種類によって異なるため, 必要に 応じて使用量を決定する。図-13 には, プライマー $200 \mathrm{~g} / \mathrm{m}^{2}$, 含浸樹脂下塗り $500 \mathrm{~g} / \mathrm{m}^{2}$, 上塗り $300 \mathrm{~g} / \mathrm{m}^{2}$ を標準 使用量として，施工後の CFRP 厚さをノギスで測定した 施工確認試験の結果を示す。試験体は，シート層数を変 えて各 4 体を施工した. この結果より, 試験体ごとに CFRP 厚みのバラツキは少なく, 樹脂の塗布量によって, 施工厚さが概敞管理できていることがわかる.

\section{b) 施工時の気温 · 湿度}

エポキシ樹脂は, 温度によって硬化時間などの特性が

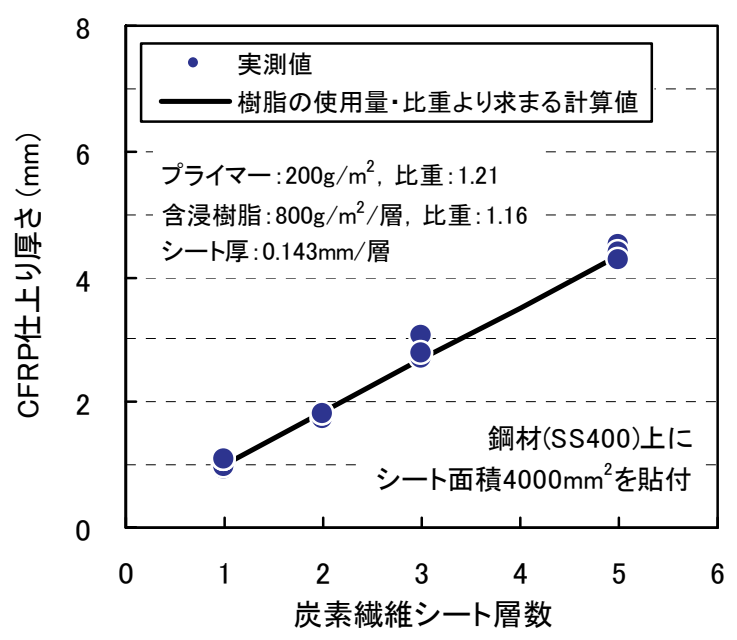

図-13 炭素繊維シート積層数と CFRP 厚さの関係 
変化することから，施工時の気温に合わせて可使時間や 硬化時間などを調整した数種類のタイプがあり，施工条 件に合わせて選択する必要がある。一般的には，低温環 境下で硬化が遅れ，粉塵等の付着，気温の急変等による 品質への悪影響を受けるので，低温下で施工寸る場合は， 施工箇所の保温養生などを検討するとよい. 一般にエポ キシ樹脂は水滴と接触すると硬化不良を起こすので，鋼 材表面に水滴がある場合や湿度が高く結露の恐れのある ときは施工してはならない．特にエポキシ樹脂の硬化時 に低温高湿度の空気にさらされると硬化剂と空気中の二 酸化炭素が反応して表面が白く濁る白化現象が生じるの で注意する必要がある．白化は層間接着不良の原因とな るので，白化が生じた場合には，アセトンなどの有機溶 剤処理やサンドペーパー掛けにより白化部分を除去しな ければならない。

\section{c) 出来形管理}

補修効果に影響を及ぼす項目として，CFRPの貼付面 積と炭素繊維シートの積層数を管理する，また，2章で 述べたように, CFRPの剥離強度に影響する接着端のず らし量も管理項目となる. 気泡を除去するために脱泡口 ーラーでしごく際に，炭素繊維シートがずれないように 注意が必要である.

\section{4. 実橋梁への適用事例}

\section{(1) 対象橋梁}

CFRPによる鋼部材腐食損傷部の補修効果を検証する ため，既設の実橋梁を対象とした現地計測を行った．計 測および検討対象とした橋梁は，図-14に示す中央自動 車道の浅利橋（下り線・右ルート）とした．本橋は，山 梨県大月市の山間部に位置し, 鋼3径間連続ワーレント ラス橋 2 連で構成される. 冬期の凍結防止剤散布などに よる厳しい腐食環境にさらされており, 塗膜の劣化およ
び腐食による断面欠損が確認された，そこで，断面欠損 が生じている部位のうち．図-15に示す下弦材を計測対 象として選定し，断面欠損量の調査および，CFRPによ る補修を実施した。

\section{(2) 腐食による断面欠損量の測定}

補修量の決定に先立って，腐食による断面欠損量の測 定を実施した. 断面欠損量の測定結果を図-16に示す. 断面欠損部の位置と平面的な大きはメジャーおよびノギ スを使用して測定し，断面欠損部の残存板厚の測定は以 下の手順により行った. まず，断面欠損部周辺の腐食が 生じていない籄所に対して, 超音波厚さ計により板厚測 定し，設計図面と照合して健全であることを確認した。 次に，断面欠損部は，急速硬化シリコンを用いたレプリ カ法により，減肉深さを測定した．図-17に示すように, 周囲の健全部にはみ出すまで, 断面欠損部にシリコンを 充填し, 硬化後に型取りしたシリコンの形状を測定する ことで, 最大減肉深さを求めた.

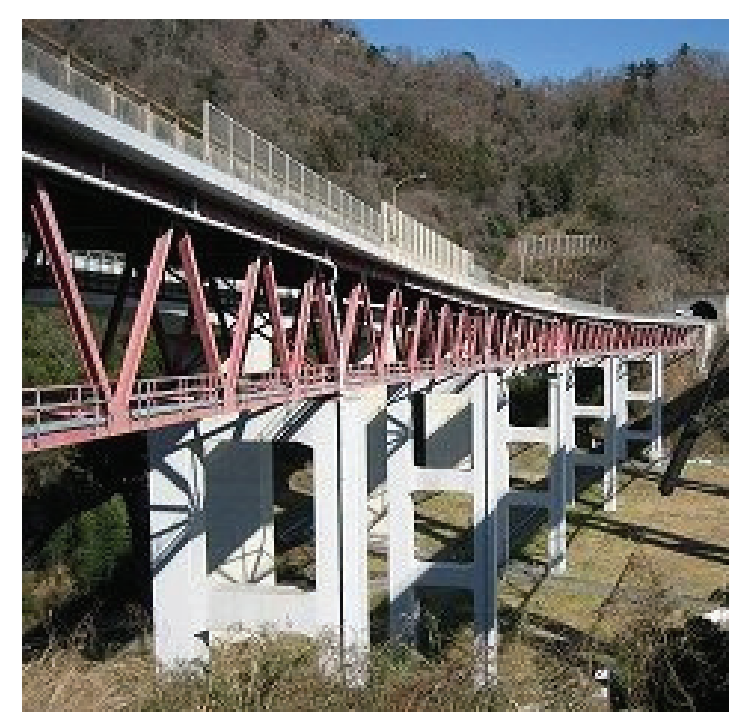

図-14 浅利橋

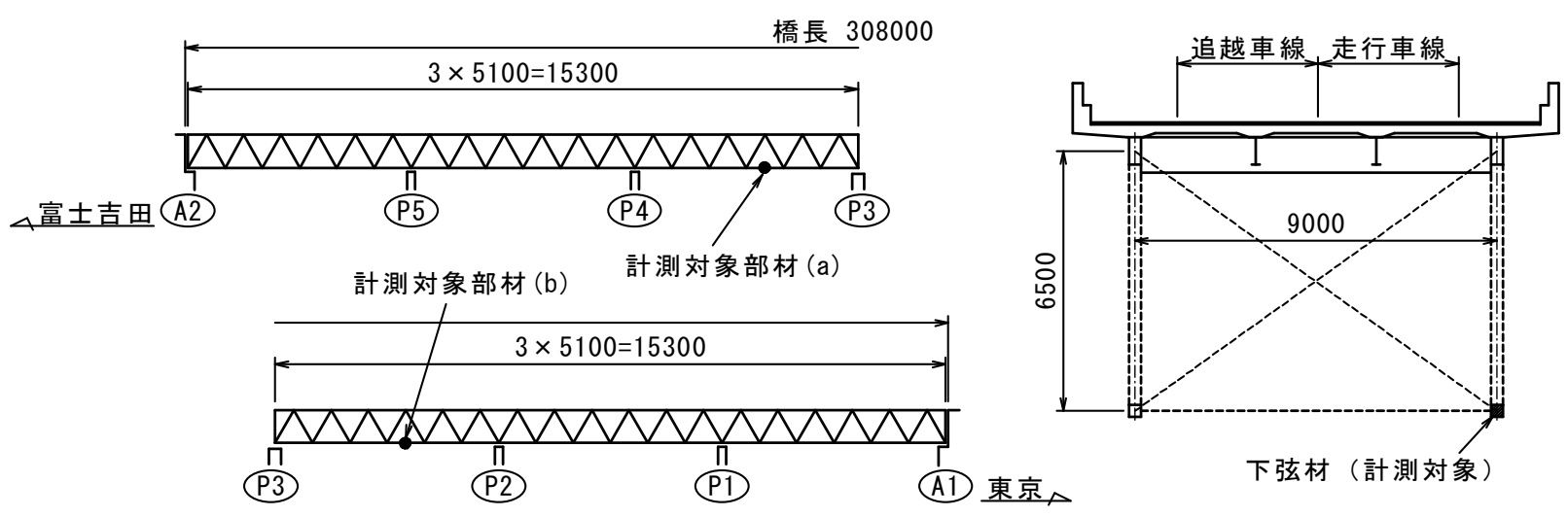

図-15 計測対象部材 


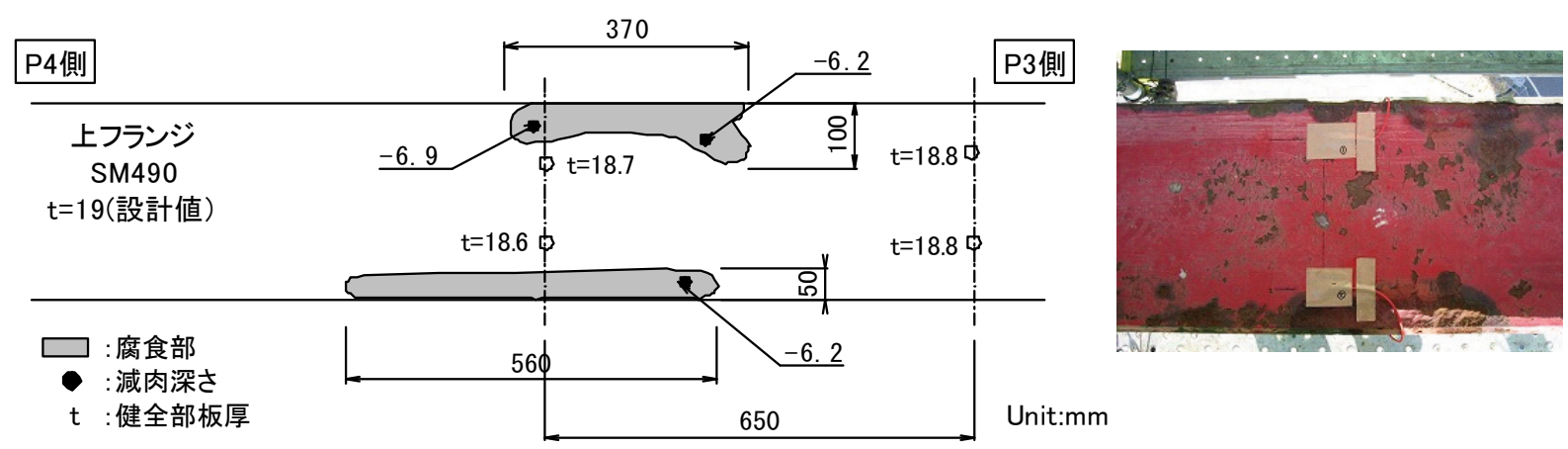

計測対象部材(a)

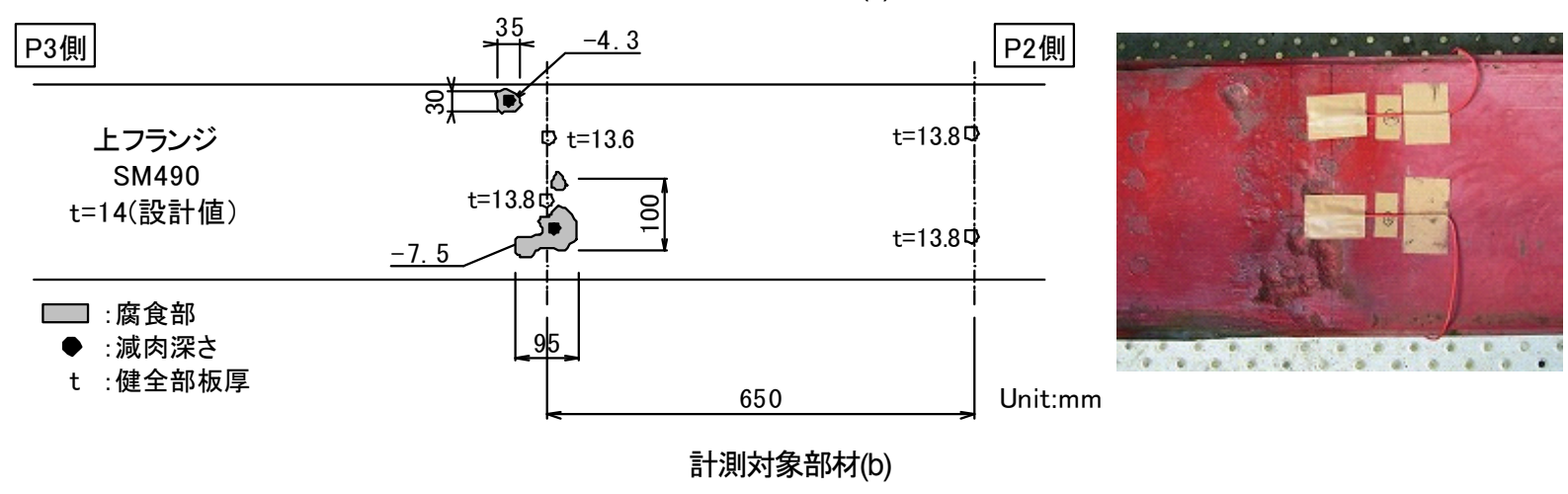

図-16 腐食減肉量の測定結果

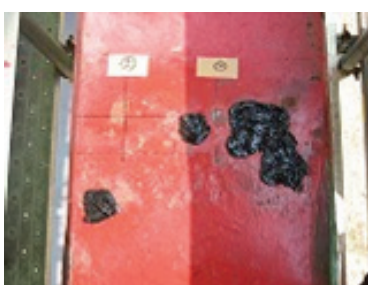

硬化後
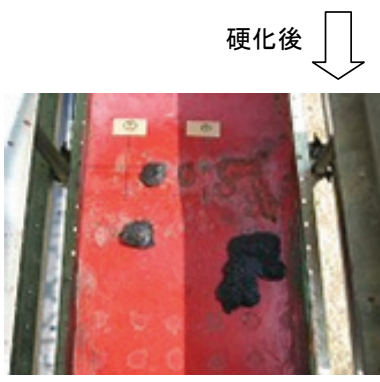

図-17 腐食減肉量の測定方法

\section{(3) 炭素繊維シートによる腐食損傷部の補修}

腐食損傷部の補修は，2 章で述べたように，断面欠損 量と同等以上の鋼換算断面積となるように，炭素繊維シ ートの積層数を決定した.

補修に使用した材料特性を表-4 に示す．施工は，3 章 で述べた手順で実施し, 施工完了後 3 日間養生した後, 計測を行った。 なお，通常は，常温下で 1 週間の養生を 行っているが，今回の施工時期は，冬期で気温が低かっ たため, ヒーターで加温養生を行った.

補修対象箇所の断面欠損量と補修量の関係を表-5に 示す.ここでは，腐食が生じているのは上フランジのみ
表-4 材料特性

(a) 炭素繊維シート（一方向材）

\begin{tabular}{l|c}
\hline 繊維目付け $\left(\mathrm{g} / \mathrm{m}^{2}\right)$ & 314 (300以上) \\
\hline 引張強度 $\left(\mathrm{kN} / \mathrm{mm}^{2}\right)$ & 2948 (1900以上) \\
\hline ヤング率 $\left(\mathrm{kN} / \mathrm{mm}^{2}\right)$ & $642(640 \pm 64)$ \\
\hline
\end{tabular}

(b) 不陸修正材 (エポキシ)

\begin{tabular}{l|c}
\hline 圧縮強度 $\left(\mathrm{N} / \mathrm{mm}^{2}\right)$ & $92(35$ 以上 $)$ \\
\hline 引張せん断強度 $\left(\mathrm{N} / \mathrm{mm}^{2}\right)$ & $17(10$ 以上 $)$ \\
\hline ヤング率 $\left(\mathrm{kN} / \mathrm{mm}^{2}\right)$ & $2.5(1.5$ 以上 $)$ \\
\hline
\end{tabular}

(c) 含浸接着材（エポキシ）

\begin{tabular}{l|l}
\hline 圧縮強度 $\left(\mathrm{N} / \mathrm{mm}^{2}\right)$ & $85 （ 70$ 以上 $)$ \\
\hline 引張せん断強度 $\left(\mathrm{N} / \mathrm{mm}^{2}\right)$ & $22 （ 10$ 以上 $)$ \\
\hline ヤング率 $\left(\mathrm{kN} / \mathrm{mm}^{2}\right)$ & 4.1 (1.0 以上) \\
\hline
\end{tabular}

※（ ）内数值は，規格值を示す.

であったが，ウェブにも炭素繊維シートを貼付すること で必要補修量を満足させた。これは，2 章で述べたよう に，部材全体としての平均応力を緩和することが目的で あり，1面あたりの炭素繊維シート積層数を低減して施 工性に配慮した結果である。また，剥離強度の向上を目 的として，接着端は $25 \mathrm{~mm}$ ずらして接着した。補修の概 要を図-18に示す. 
表-5 断面欠損量と炭素繊維シート補修量

\begin{tabular}{|c|c|c|c|c|c|c|}
\hline \multirow{2}{*}{ 部材 } & \multirow{2}{*}{$\begin{array}{l}\text { 設計断面 } \\
\text { (mm) }\end{array}$} & \multirow{2}{*}{$\begin{array}{c}\text { 減肉量 } \\
(\mathrm{mm})\end{array}$} & \multirow{2}{*}{$\begin{array}{c}\text { 欠損断面積 }\left(\mathrm{mm}^{2}\right) \\
\text { [断面欠損率※1 }]\end{array}$} & \multicolumn{3}{|c|}{ 炭素繊維シート } \\
\hline & & & & 補修量 ${ }^{2}\left(\mathrm{~mm}^{2}\right)$ & 幅(mm) & 層数(枚) \\
\hline \multirow{3}{*}{ (a) } & U.Flg $300 \times 19$ & $\begin{array}{c}100 \mathrm{~B} \times 6.9 \mathrm{t} \\
50 \mathrm{~B} \times 6.2 \mathrm{t}\end{array}$ & \multirow{3}{*}{$\begin{array}{c}1000 \\
{[6.0 \%]}\end{array}$} & \multirow{3}{*}{$<1030$} & 250 & 3 \\
\hline & Web $300 \times 10$ & - & & & $250 \times 2$ 面 & 3 \\
\hline & L.Flg $360 \times 14$ & - & & & - & - \\
\hline \multirow{3}{*}{ (b) } & U.Flg $300 \times 14$ & $\begin{array}{c}30 \mathrm{~B} \times 4.3 \mathrm{t} \\
100 \mathrm{~B} \times 7.5 \mathrm{t}\end{array}$ & \multirow{3}{*}{$\begin{array}{c}879 \\
{[6.2 \%]}\end{array}$} & \multirow{3}{*}{$<1030$} & 250 & 3 \\
\hline & Web $300 \times 10$ & - & & & $250 \times 2$ 面 & 3 \\
\hline & L.Flg $360 \times 11$ & - & & & - & - \\
\hline
\end{tabular}

$※ 1$ : 設計総断面積に対する久損断面積の比率

$※ 2$ : 炭素繊維シートの鋼換算断面積は，表-3に示寸材料規格值で計算した
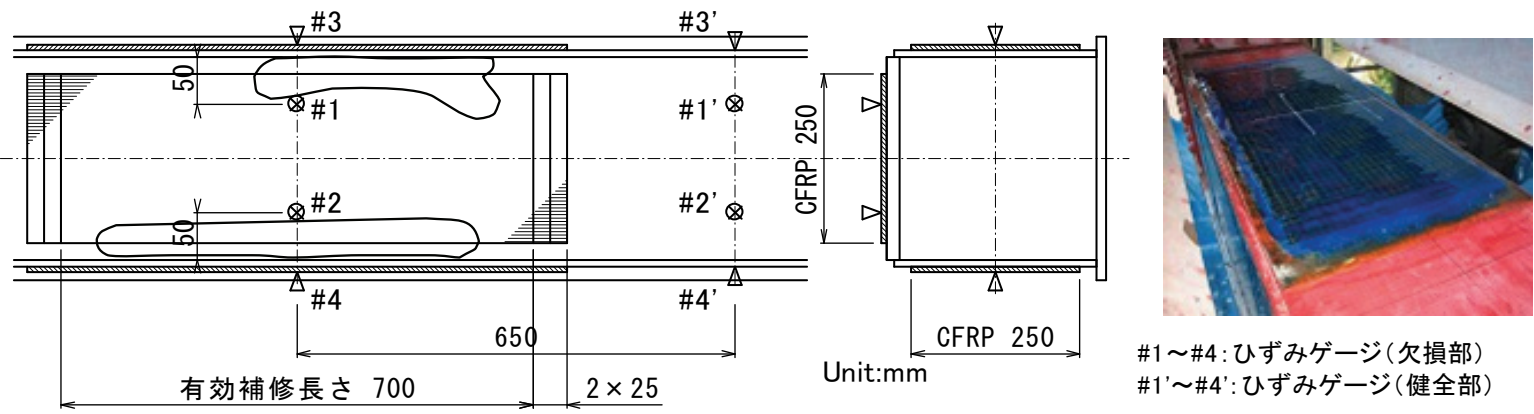

計測対象部材(a)
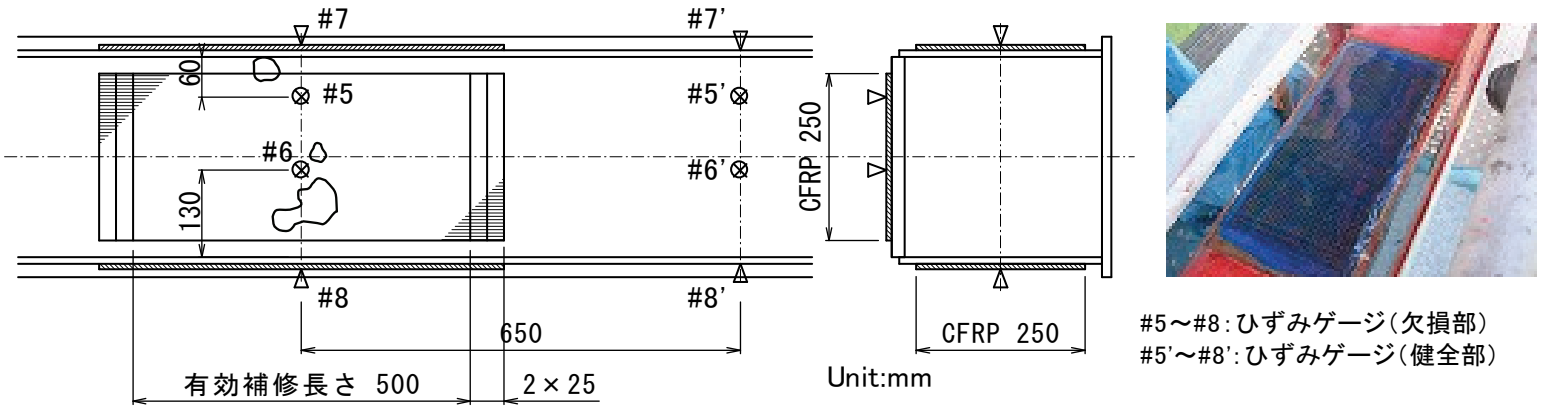

\#5 \#8:ひずみゲージ(欠損部) \#5'〜\#8': ひずみゲージ(健全部)

計測対象部材(b)

図-18＼cjkstart炭素繊維シートによる補修

\section{(4) 計測方法}

補修前と補修後に, 同一条件で試験車両を走行させ, 動ひずみを計測し，両者を比較することで補修効果を検 討するものとした．また，補修前後に実交通下での忘力 頻度計測も行った. 各計測条件を表-6 に示す. 試験車 両は，車両重量を 22ton に調整した散水車を走行させた. $80 \mathrm{~km} / \mathrm{h}$ の一定速度で走行し, 一般車両の無いタイミン グを見計って計測を行った。載荷車線は，図-15に示し た追越車線および走行車線の 2 ケースとした. 応力頻度 計測は，交通条件の異なる土，日曜を避けた平日に実施 し，補修前と補修後にそれぞれ 24 時間の計測を行った. ひずみゲージの貼付位置を図-18に示す。欠損断面
表-6 計測条件

\begin{tabular}{c|c|c}
\hline 項目 & 時期 & \multicolumn{1}{|c|}{ 条件 } \\
\hline 動的ひずみ & 補修前 & ・試験車両 $(22 \mathrm{t})$, 速度 $80 \mathrm{~km} / \mathrm{h}$ \\
\cline { 2 - 2 } 計測 & 補修後 & ・走行車線および追越車線 \\
\hline \multirow{2}{*}{$\begin{array}{c}\text { 応力頻度 } \\
\text { 計測 }\end{array}$} & 補修前 & \multirow{2}{*}{ ・平日 24時間 } \\
\cline { 2 - 2 } & 補修後 & \\
\hline
\end{tabular}

（\#1〜\#8）と健全断面（\#1'〜\#8'）にひずみゲージを貼付 し，久損断面のひずみゲージは，補修前の計測終了後に いったん撤去し，CFRPを施工した後，再び同じ位置に 貼付した. 


\section{(5) 試験車両載荷による動ひずみ計測結果}

試験車両の走行時に得られたひずみ波形の例を図-19 に示す．なお，ひずみゲージ貼付時と計測時の気温差な どの影響を排除するため，この波形は，車両通行が無い 時のひずみ平均值が0になるようにデータ処理を行った ものである．この結果より，補修前に比べて補修後の動 ひずみピーク值が下がっていることがわかる.

補修前と補修後に計測した動ひずみ波形より，ひずみ のピーク值を整理した結果を図-20，図-21に示す．図は, 走行車線載荷時と追越車線載荷時に得られた值の平均值 である。ここでは，補修前と補修後の計測時に試験車両 の走行ラインの差違など，載荷条件の違いによる影響が 考えられるため, 計測条件の差違を極力排除するために, 健全断面のひずみ最大值に対する欠損断面のひずみ最大 值の比率で整理した. これらの結果より，以下のことが わかる。

1）補修前は断面欠損のある上フランジでは，健全部に 比べて発生ひずみが大きい，特に，周囲が久損部に 囲まれている\#6では，応力集中の影響が大きいと考 えられる.

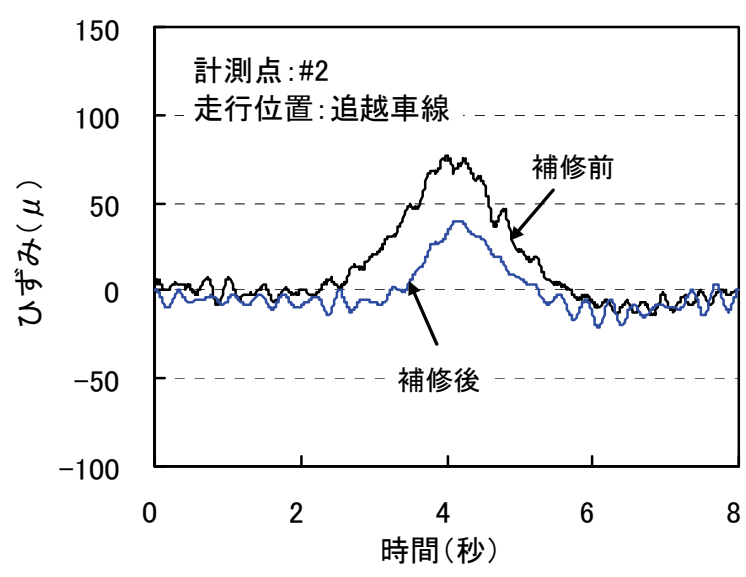

図-19 試験車両通過時のひずみ波形

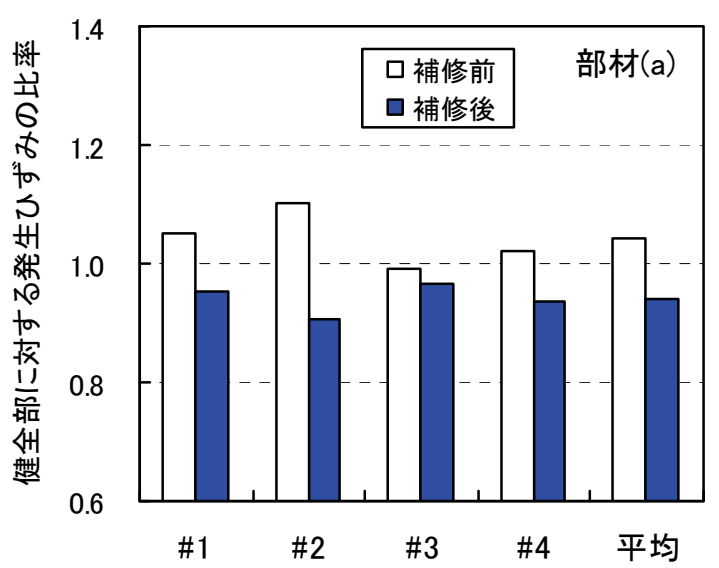

図-20 補修前後の最大ひずみ（部材 a )
2) 炭素繊維シートを貼付することにより，発生ひずみ が低下寸る. 断面欠損のないウェブでは，\#3と\#7で 約 $97 \% ， \# 4$ と 8 で約 $91 \%$ 発生ひずみが低減し，両 部材とも同様に補修効果が得られている.

3）断面欠損がある上フランジでは，より大きな補修効 果が得られており，\#1と\#2の平均で約 $86 \%$ ，\#5 と\#6 の平均で約 $87 \%$ に発生ひずみが低減した.

4)部材の平均值では．部材(a)，部材(b)ともに約 $90 \%$ に 発生ひずみが低減した．両部材の断面欠損率は, 6\%程度であったことから，設計時の初期性能を回 復，もしくは現状維持を目的と寸れば，十分効果的 であるといえる.

\section{(6) 応力頻度計測結果}

動ひずみ計測時に，発生ひずみの大きかった非 位置 の健全断面と欠損断面について，補修前後の応力頻度分 布を図-22, 図-23 に示寸，本結果は，変動応力下での波 形処理方法として広く用いられているレインフロー法 ${ }^{18)}$ によって，整理したものである．なお，図中の $\sigma_{r q}$ は， 応力頻度分布によって部材が受ける損傷度と等価な損傷 度を与える等価応力範囲である ${ }^{18)}$. 本工法は疲労対策を 目的としたものではないが, 補修効果検証の一指標とし て示した.

健全断面では，補修前と補修後の頻度分布に大きな差 異は見られないが，欠損断面では頻度分布の形状が，補 修によって応力が下がる方向にシフトする傾向にある. 欠損断面での等価応力範囲は，補修によって 94\%に低減 される.これらの結果より，供用荷重下においても，本 工法の適用によって, 断面欠損部の応力が改善されるこ とが確認された。また，母材に生じるピーク応力は $50 \mathrm{~N} / \mathrm{mm}^{2}$ 程度であり, 図-11に整理した CFRP の剥離荷 重より，常時荷重作用下において CFRP の剥離が生じる 可能性は，ほとんどないと考えられる.

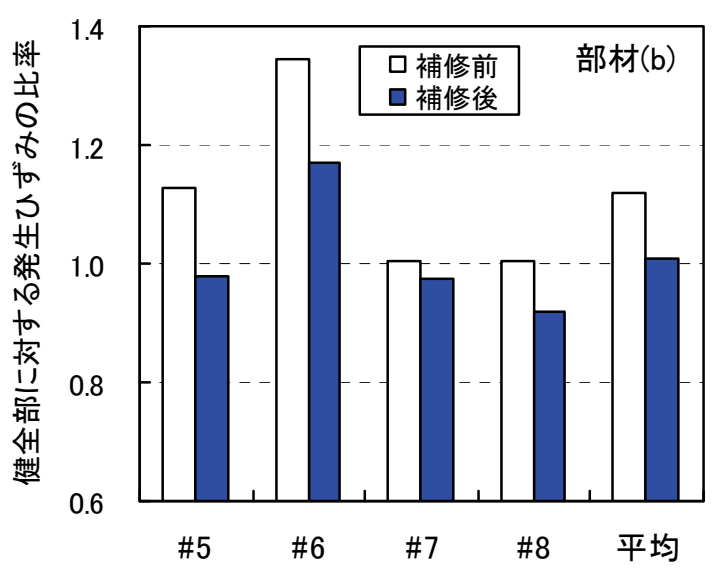

図-21 補修前後の最大ひずみ（部材 $b$ ) 


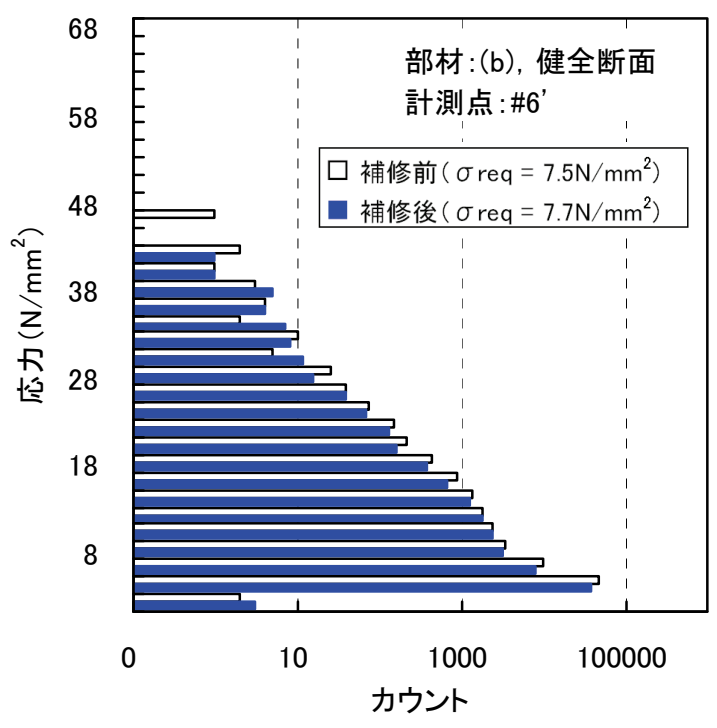

図-22 応力頻度計測結果（健全断面）

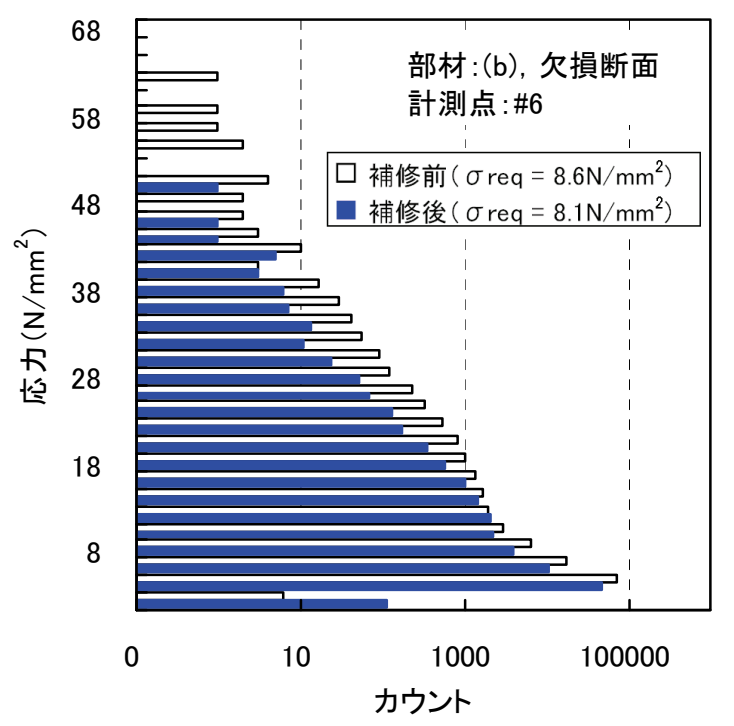

図-23 応力頻度計測結果（欠損断面）

\section{5. まとめ}

腐食により断面欠損した鋼部材に対して，炭素䋊維 シートを貼り付けることによる補修方法を開発した。本 稿では，その設計・施工法の考え方を示し，既存の実橋 梁への適用事例を紹介した. 本文の内容を要約すると, 以下のとおりである.

1) 本工法の適用範囲と補修設計の考え方を示した。本 工法は，従来の当て板補修に比べて施工性に優れ， 母材を傷めないため，施工スペースの制約がある供 用中の補修や，塗装塗替え工事の前補修工事に適す る．また，本工法で使用する強化繊維および樹脂材 料の特徵を紹介し，補修対象部材の久損断面積に応 じた補修量の計算方法, CFRPの剥離強度について, 基礎試験の結果を含めて示した。
2) 本工法の施工方法について，その詳細手順の説明と ともに，各工程の目的と必要性を示した．また，特 に注意すべき施工上の留意点を示した。

3）既設の実橋梁を対象とした施工事例を紹介した．鋼 材の腐食による断面欠損部を対象に，その減肉量を 計測し，設計時の初期性能への回復を目的とした補 修を実施した。また，試験車両載荷による動ひずみ 計測および供用荷重下における応力頻度計測を実施 し，補修前後の発生ひずみを比較した。 その結果, 所要の補修効果が得られることを実証した。

\section{6. おわりに}

炭素繊維シートを用いた補修工法は，薄く軽量な炭素 繊維シートを接着剤で貼付するため施工性に優れ，供用 中の鋼構造物の腐食損傷部を効率的に補修することがで きる.しかしながら，本工法は，常時何重作用下で母材 が弾性挙動する範囲, すなわち炭素繊維シートの剥離が 生じない範囲での適用が前提となるため, 適用に際して は，損傷の種別や程度，補修目的，対象部材の応力状態 等を十分検討し，鋼板当て板などの従来工法も含めた工 法選定が重要であると考える. また，常時荷重作用下に おける疲労剥離強度や，屋外自然環境下における劣化度 合いなど，長期耐久性に関するデータの蓄積が，本工法 の信頼性向上に向けた今後の課題と考える.

\section{参考文献}

1) 土木学会 : 鋼橋における劣化現象と損傷の評価, 1996.10

2) 渡邊憲市，板垣一也，鈴木博之 : 炭素繊維強化樹脂板による 鋼橋の補強，鋼構造年次論文報告集，第 8 巻，日本鋼構造協 会, pp.679-682,2000.11

3) 中村一史, 諸井敬嘉, 鈴木博之, 前田研一, 入部孝夫 : 溶接 継手に発生した疲労き劣の CFRP 板による補修, 鋼構造年次 論文報告集，第 12 巻，日本鋼構造協会，pp.425-430,2004.11

4) 石井博典, 小林朗, 吉川紀, 北城正樹 : 炭素繊維プレートを 用いた既設鋼桁橋の補強に関する検討，土木学会第 58 回年 次学術講演会講演概要集，CD-ROM，I-454，2003.9

5) 稲葉尚文, 冨田芳男, 紫桃孝一郎, 鈴木博之, 岡本陽介 : GFRP シート貼付によるリブ十字溶接継手の補強に関する一 提案，土木学会論文集，No.798/VI-68，pp.89-99,2005.9

6) 渡辺貴之, 石田圭吾, 林和彦, 山口隆裕, 池田尚司 : 炭素繊 維シートを用いた鋼製橋脚の而震補強, 構造工学論文集,

Vol.48A, pp.725-734, 2002.3

7) 土木研究センター : 炭素繊維シートによる鋼製橋脚の補強工 法ガイドライン(案), 2002.7

8) 道路保全技術センター：3. 実用を目的とした性能評価指標の 検討, 保全評価部会性能評価委員会平成 15 年度報告書, 2003.

9) 土木学会複合構造委員会 : 複合構造技術の最先端一その方法 と土木分野への適用一, 複合構造シリーズ $03,2007.7$ 
10) 日本複合材料学会 : 複合材料活用辞典, pp.338，2001.

11) 杉浦江，大垣賀津雄，冨田芳男，稲葉尚文，長井正嗣，小 林朗 : 炭素繊維シート (CFRP) による鋼構造物の補修に関 する基礎実験，土木学会第 61 回年次学術講演会講演概要集, CD-ROM, I-658, 2006.9

12) 杉浦江，大垣賀津雄，稲葉尚文，冨田芳男，長井正嗣，小 林朗 : 炭素䋊維シートを用いた腐食による鋼部材断面欠損 部の補修効果に関する実験的研究, 構造工学論文集, Vol.54A, pp.548-554, 2008.3

13) 杉浦江, 小林朗, 大垣賀津雄, 稲葉尚文, 冨田芳男, 長井 正嗣 : 鋼部材腐食損傷部の補修における炭素繊維シート接 着方法に関する解析的研究, 土木学会論文集 A, Vol.64, No.4, pp.806-813,2008.

14) 玉井宏章, 高松隆夫, 服部明生, 灰谷徳治, 櫻庭誠 : 炭素 繊維プレートによる鋼構造物の接着補強工法に関する基礎 的研究, 鋼構造年次論文報告集, 第 14 巻, 日本鋼構造協会, pp.445-452, 2006.11

15) 杉浦江, 大垣賀津雄, 長井正嗣, 小林朗 : 炭素䋊維シート （CFRP）を用いた鋼部材部分補修に関する実験研究，第 6 回複合構造の活用に関するシンポジウム講演論文集, pp.48$1-48-6,2005.11$

16) 杉山哲也, 小林朗, 斉藤誠 : 炭素繊維複合材料の耐久性評 価, 新素材のコンクリート構造物への利用シンポジウム論 文報告集，日本コンクリート工学協会北海道支部，pp.49-56， 1996.11

17) 中井章人, 北田俊行, 松村政秀 : 炭素繊維接着による鋼板 の電食に関する一考察, 第 6 回複合構造の活用に関するシン ポジウム講演論文集, pp.46-1-46-4, 2005.11

18) 日本道路協会 : 鋼橋の疲労, 1997.

(2008.4.30 受付)

\section{A PROPOSAL OF DESIGN AND CONSTRUCTION METHOD OF REPAIR FOR CORRODED STEEL MEMBERS BY CARBON FIBER SHEETS}

\section{Hiroshi SUGIURA, Akira KOBAYASHI, Naofumi INABA, Atsushi HOMMA, Kazuo OHGAKI and Masatsugu NAGAI}

The deterioration of performance of steel structures comes from various reasons. One of main reasons of such deterioration is the corrosion of steel. When the corrosion has reached advanced stage with reduced thickness, causing overstress, the repairing method will be the stress reduction measure such as steel plate attachment by bolting or welding to the corroded member. However, these methods need largescaled scaffold and equipments at site. Hence, it is very useful to develop an effective repair method for the actual steel structures in use.

We developed a new repair method for corroded steel members by carbon fiber sheets. This paper describes the design and construction method of our proposed repair method, and reports the results of the confirmation test of the repair effect at the existing bridge. 